\title{
KNOWLEDGE TRANSFER AT UNIVERSITIES: \\ CAN TECHNOLOGY TRANSFER OFFICES, BUSINESS \\ INCUBATORS AND SCIENCE AND TECHNOLOGY \\ PARKS IN POLAND PROVIDE GOOD SUPPORT SERVICES?
}

\author{
KATARZYNA ŁOBACZ \\ University of Szczecin, Faculty of Management and Economics of Services, POLAND \\ e-mail: katarzyna.lobacz@wzieu.pl
}

\author{
\begin{tabular}{l|l} 
RECEIVED & 6 November 2018
\end{tabular} \\ ACCEPTED 3 December 2018 \\ JEL \\ CLASSIFICATION \\ L30, O31, O33
}

KEYWORDS knowledge transfer, universities, support services, technology transfer offices, business incubators, science and technology parks

ABSTRACT It has been widely recognised that technology transfer offices (TTOs), business incubators (Bls) and science \& technology parks (STPs) - operating as university units - are a very important part of the commercialisation process of knowledge at universities. However results which are obtained through support services they provide doesn't always satisfy expectations. Therefore the paper analyses challenges and barriers faced by TTOs, Bls and STPs, which affect results from provided services. The analysis is based on the square-shaped framework with mutually related factors distinguished, encompassing legal and organizational context of knowledge commercialization at public universities. The results suggest that both legal and environmental context as well as social relationships affect strongly results of university dependent TTOs, Bls and STPs.

\section{Introduction}

Accumulation and use of knowledge are becoming increasingly important in the development of modern economy. According to the concept of the knowledge-based economy, knowledge is a key production factor that determines sustainable economic growth (Zienkowski, 2003, pp. 12-32; Shane, 2004, pp. 15-39; Kozmetzky, Williams, Williams, 2004, pp. 1-22; Acs, Braunerhjelm, Audretsch, Carlsson, 2009, pp. 15-30; Dosi, Nelson, 
2010, pp. 51-127; Deiaco, Hughes, McKelvey, 2012, pp. 525-541). For this reason, many scientific efforts as well as political aspirations are directed towards the development of knowledge and an increase in the level of its commercial use.

Universities can play a vital role in this process, especially through effective use of an instrument, which is given - establishment of a specialised university units providing support services in this regard, such as technology transfer offices (TTOs), business incubators (BIs) and science and technology parks (STP). Although tasks which should be performed by those university bodies are generally known (e.g. Łobacz, 2012; Łobacz, Niedzielski, 2015a; Głodek, 2016; Głodek, Stawasz, 2017), lack of satisfaction from results of those actions are observed at many universities in Poland and other countries (Davey et al., 2018, pp. 5-16).

Remarks, based on analysis of case study from many developed and developing countries, add arguments to the discussion about effective approaches to designing systems supporting commercialization of knowledge at universities (Davey et al., 2018, pp. 117-144). Many analyses in the field reveals that although those support systems were improved in recent years in many developing countries (including Poland), these are not always effective 'real' actions (Matusiak, Gulinski, 2010, pp. 20-48; Trzmielak, 2013).

Therefore it seems important to look deeply for reasons of the observed situation, which is the aim of this paper. Based on the detailed framework describing conditions of knowledge commercialisation process at universities defined by K. Łobacz and P. Niedzielski (2015b), analysis discusses relationships between challenges and barriers faced by technology transfer offices, business incubators and science parks being parts of public universities in Poland, and other factors affecting knowledge transfer at those universities. Conclusions from the study are very useful for decision makes, at different levels, to include policy makers, university authorities and academics.

\section{Knowledge transifer at universities: barrierrs and challenges faced by TTOs, Bls and STPS}

It has been widely recognised that TTOs, Bls and STPs are a very important part of the knowledge commercialisation process at universities. They are responsible for collecting information about scientific discoveries, evaluation of commercialisation potential of those discoveries and supporting scientists in creation and development of their entrepreneurial ventures based on knowledge they are willing to commercialise. But, to perform those actions, they have to deal with many barriers and challenges related to the process itself, and, if they are parts of university, they are additionally highly dependent on rules governing university actions, both formal and informal ones.

There can be identified, three main aspects which affect the results achieved by TTOs, Bls and STPs as facilitators of knowledge commercialisation at universities: human resources potential, financial stability and access to information (Łobacz, Niedzielski, 2015a). In this regard TTOs, Bls and STPs should be perceived, just as universities are, as entities which are partly dependent upon business rules, and partly are public servants. The discussion present in the literature in relation to those three distinguished aspects can be summarised as follows.

Human resources potential. The possibility of active involvement of university TTOs, Bls and STPs in the process of commercialisation is essentially limited by the insufficient personnel potential. The problem is related to two factors in particular: a relatively low employment level in these units (Matusiak, Guliński, 2010, pp. 20-48), and competence deficiencies of the employed staff. Both factors are to a large extent a consequence of financial constraints, including a lack of long-term stability of financing. 
In Poland, the insufficient potential of human resources in TTOs, Bls, STPs organized in order to support and promote involvement of academic community in entrepreneurial actions and technology transfer is clearly observable. Often, even in the structure of large universities (employing more than one thousand academic employees), one can encounter centres employing 1-2 persons. This is not enough to undertake actions on a noticeable scale, and in principle, only enables relatively simple forms of commercialisation which implementation requires only a relatively short time commitment.

Additionally many TTOs, Bls, STPs face limitations related to the competences of the staff employed. The financial conditions offered do not allow the employment of staff with practical experience, hence many employees of the centres begin to learn in the course of their work. In addition, the outflow of experienced staff to more attractive employers is a real threat. The implementation of external projects is not conducive to reducing the problem of staff deficit. Although it results in a temporary increase in employment, new employees are obliged to implement activities related to a specific project, which usually does not directly involve commercialisation of knowledge, and there is little chance of employing in this way people with relevant professional experience.

Financial stability. An important issue related to active support of commercialisation of knowledge by TTOs, Bls and STPs at universities is a lack of financial stability. It refers primarily to taking actions that require a longer time horizon, and its consequences are, above all, a lack of focus on supporting knowledge commercialisation processes in the long-term in favour of concentrating on obtaining financing necessary to cover the costs of current operations; and a lack of opportunities to cooperate with good specialists requiring higher rates for their services (Clark, 1998, pp. 127-148; Trzmielak, 2013; Lobacz, Niedzielski, 2015a). The lack of stable and adequate (to potential tasks) sources of financing makes it necessary to concentrate the activities more on obtaining financing for their operations, than on operations themselves.

The lack of financial stability additionally limits the possibilities of employing external specialists, both permanently and as experts and advisers, e.g.: in the field of assessing the commercial value of projects, creating business plans, etc. (Łobacz, Głodek, 2011; Łobacz, Głodek, 2012). Additionally, this implies a lack of possibility of employing the so-called substitute entrepreneurs whose participation in the international commercialisation of new technologies is indispensable in models found in highly developed countries (see the incubator model Clarysse, Heirman, Degroof, 2005).

Lack of financial stability of bodies involved in commercialisation of knowledge at Polish public universities is visible. The lack of clearly stated long term budgets makes it necessary to engage a lot of resources and effort (which are anyway very much limited) on obtaining financing for their operations. In this situation, the main source of income is the implementation of broadly understood projects financed from public grants. They ensure ongoing financial support of these units, but this means that the centre's activity is focused on actions loosely related to commercialisation of knowledge such as promotional and training activities, etc. In consequence, the scope of activities is controlled largely by the current availability of external financial resources for particular purposes.

Access to information. The specificity of the functioning of higher education institutions in the context of their potential to commercialise knowledge may imply a large dispersion of information about the scope of activities and knowledge that can be commercialised. In this area, key problems that have an impact on the commercialisation process include especially: a degree of openness of the scientific community to cooperation and knowledge sharing; a system of information acquisition; and a system of obtaining and sharing information. Those issues have been acknowledged as highly important as they have an impact on opening or closing options for commercialisation for 
university, who want actively participate in this process (Clark, 1998, pp. 127-148; Dietz, Bozeman, 2005; Matusiak, Gulinski, 2010, pp. 20-29).

It can be observed that the barriers and challenges described above are dependent on external factors. This means, that in fact many factors - not dependent on TTOs, Bls and STPs management and involvement impact success or failure (also scope and quality) of support that these organisations provide. Therefore is seems reasonable to identify reasons of those problems, which will enable to propose real solutions able to overcome existing barriers.

\section{Method}

The analytical framework, used for discussion, emphasize distinctive problem levels related to processes of knowledge commercialisation at public universities with its problem areas and specific problem factors distinguished within each of the areas (Łobacz, Niedzielski, 2015b). As it incorporates also external, university independent factors, it can be used to analyse challenges and barriers to commercialisation at universities in particular environment. The specific aspects captured within the model has been summarised in Figure 1.

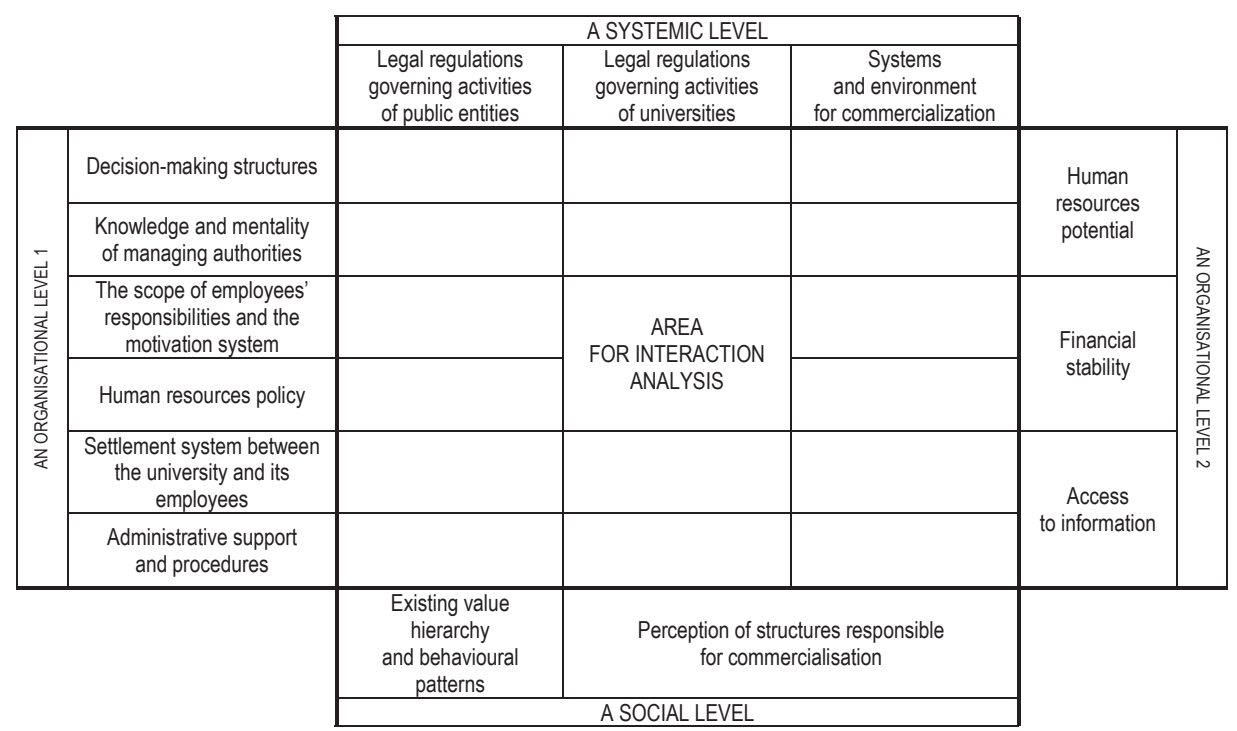

Figure 1. Square-shaped framework of analysis of knowledge transfer barriers and challenges at universities

Source: adaptation based on Łobacz, Niedzielski (2015b).

The existence of links between the individual diagnosed problems means that there is a need to look for cause-and-effect relationships. Therefore all factors distinguished in the analytical model has been organised in a square-shaped framework. This kind of organisation, very simple in its nature, provides a space in which all relationships between subsequent factors can be easily identified, and thus aspects with highest impact and, furthermore, consequences of this impact can be easily determined. 


\section{Barriers and challenges faced by TTOS, Bls and STPS: Iooking for reasons and relationships}

Based on the framework used for analysis, there has been distinguished main relationships between all aspects affecting commercialisation process and their impact on actions performed by TTOs, BIs, STPs. All those have been shown at Figure 2 and discussed below. The analysis suggest that behaviours and actions of TTOs, Bls, STPs are highly dependent on legal and environmental systems governing actions of universities, as well as social relationships regulating in general behaviours of academic community. Additionally financial stability of TTOs, Bls, STPs affect their human resources potential and accessibility to good sources of information.

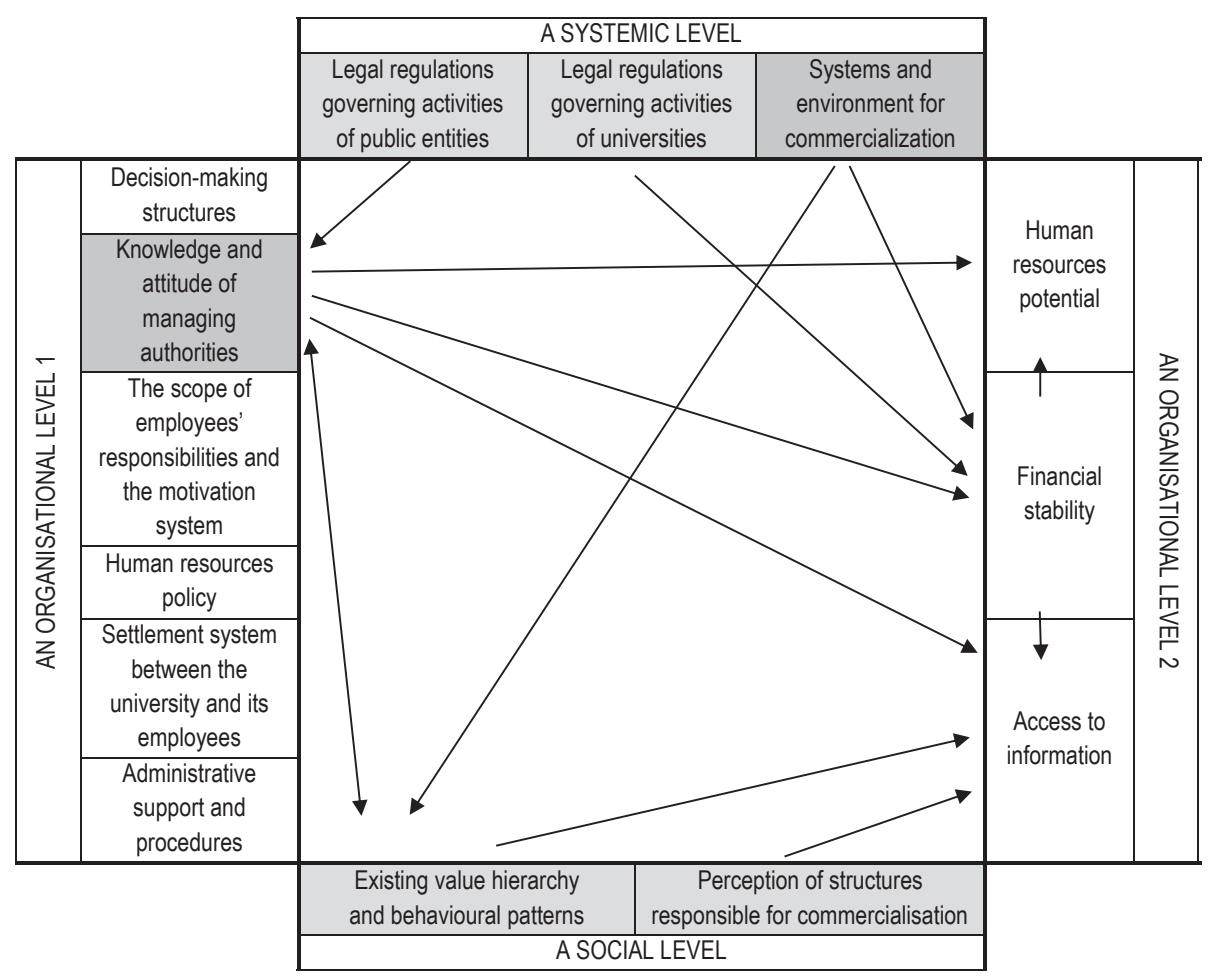

Figure 2. Relationships between the problem areas in relation to barriers and challenges faced by TTOs, Bls and STPS Source: own.

Since the processes taking place at universities are influenced by the broadly understood environment, the high quality of the environment in which a given university operates facilitates processes of commercialisation, and vice versa - the limitations resulting from environmental deficiencies increase the challenges and problems that a given university faces in terms of commercialisation (Mowery, Sampat, 2004; Clark, 1998, pp. 127-148). Among the factors that can limit commercialisation processes from this point of view, at least five should be mentioned.

First one is willingness of the environment to cooperate with universities. Second one is proximity and availability of markets absorbing new solutions. Third one relates to availability and quality of human and institutional 
resources related to knowledge commercialisation and technology transfer. And finally availability of capital that can be used to commercialise knowledge, and availability of behavioural patterns (the so-called success stories), should be mentioned as fourth and fifth issues. All these affect to a large extent financial stability of TTOs, Bls, STPs, and behavioural patterns of academic staff, which furthermore result in problems of access to information.

The existing public procurement law causes great difficulties in making decisions, in particular market decisions, freely. Paradoxically, the public procurement law, designed to safeguard the way public funds are spent, in many cases necessitates the undertaking of highly ineffective actions. In addition, legal restrictions associated with commercialisation processes reduce the competitiveness of solutions available at universities in relation to other solutions available in the market. All this results in the rational decision of university authorities to resign from conducting activities associated with knowledge commercialisation.

Apart from overall legal regulations, which generally impose certain restrictions on public entities, universities are subject to additional regulations, which may also constitute a significant barrier to activities related to commercialisation of knowledge and technology transfer (Chiesa, Piccaluga, 2000; Howard, 2005; Trzmielak, 2013). These include in particular legal regulations regarding the creation of academic spin-off companies and legal regulations regarding the ability to manage the budget related to commercial activity.

Financial constraints to which universities are subject are a significant limitation in terms of strategic thinking about knowledge commercialisation (Howard, 2005). This applies in particular to the purposeful nature of the subsidies obtained, which may be used only to a small extent of activities related to technology transfer, including, for example, the stable operation of a technology transfer centre or an academic business incubator.

In addition, an insufficient experience of university authorities (and often a lack of it) in terms of knowledge commercialisation results in a lack of awareness of the issue and its complexity. This usually implies pushing the issue to the margin of universities' activity, and even neglecting it to a significant degree. As a result, the function of technology transfer may be delegated to university units that do not have sufficient secured (financial, human, knowledge) resources.

Social relationships affecting attitudes and behavioural patterns are to large extend result from existing external regulations and requirements stated by university authorities governing actions, but are also a consequence of rules rooted in traditional academic culture built for many years at universities. Those rules and relationships form a framework in which TTOs, Bls, STPs can perform their actions, and especially affect access to information about new discoveries with commercialisation potential and cooperation willingness, which are necessary conditions of effective support services.

The values cultivated by the academic community influence various areas of behaviour, including behaviours related to commercialisation of knowledge and technology transfer (Clark, 1998, pp. 127-148, Łobacz, Niedzielski 2015b). Significant barriers resulting from the attitude of scientific employees include in particular a lack of general acceptance of activities related to commercialisation of knowledge; the perception of the superiority of basic research over applied research; the perception of the university as a unit generating knowledge and not transforming it into a product; a different perception of the research stage by scientists and entrepreneurs; considering of earning money from commercialisation as inappropriate.

The access to information, especially about technologies that could be potentially commercialised, at Polish universities is thus limited. Historically rooted significant independence of organisational units at universities (in particular, departments and institutes), and sometimes also individual researchers, in the scope of shaping their 
own research profile and research plans, translates into a small degree of coordination of research projects at the faculty or university level. This result in a small degree of openness of the scientific community to cooperation and knowledge sharing.

Additionally, the highly formalised and, therefore, ineffective scope of reporting on current research activity and the research results achieved means that the reporting processes do not take into account the assessment of commercial potential of the research results achieved, as they are subordinated to, among others, the requirements of the parametric evaluation process of scientific institutions. Created databases of projects with a commercial potential and databases of research teams along with the services they offer very quickly become outdated, and there is a shortage of personnel that can devote time to updating this information on a current basis. The superficial and low level of communicativeness of the information contained therein is also a barrier to the practical use of existing databases.

In the process of obtaining information on potential commercialisation projects, one of the barriers is the low degree of openness of the scientific community to cooperation and knowledge sharing. The factors related to this barrier include the perception of the university and its units rather as the supervisor and controller of the use of a given university's IP than as a partner in the commercialisation process; a lack of trust in confidentiality procedures concerning information about technology and the commercialisation process itself; a lack of trust in colleagues regarding the use of generated ideas; and no examples of cooperation.

\section{Conclusions}

The analysis of cause and effect relations of aspects affecting knowledge commercialisation at public universities indicates that scope and quality of support services provided in this regard by TTOs, Bls, STPs are highly dependent on external factors, like environment and legal regulations governing university actions, as well as internal factors, regulating employees behavioural patterns and attitudes. All those affect human resource potential, financial stability and access to information of university bodies established to promote commercial use of university knowledge in business environment.

Financial stability of TTOs, Bls, STPs seems to be highly dependent not only from regulations governing directly legal frames in which they can operate, but also regulations to which universities are subordinates. Although in recent years the barriers related to commercialisation itself have been largely removed, the rules related to the public finance discipline are still an important obstacle. These rules significantly determine the organisational behaviours at universities.

Social relationships on the other hand, regulate strongly access to information, which TTOs, Bls, STPS can use to provide their services. In contrary, human resources potential of TTOs, BIs, STPs seems to be highly dependent on knowledge and attitude of university managing authorities, being to a large extent a result of legal regulations governing activities of public entities and existing value hierarchy and behavioural patterns. In order for a significant change to take place, it is necessary to alter the attitude of the academic community. The adoption of an entrepreneurial orientation by universities entails the necessity to change the perception of entrepreneurial behaviours that have been considered inappropriate, inferior, unnecessary and not worthy of recognition (Etzkowitz, Webster, Gebhardt, Terra, 2000). 
The contextual and social baggage is the factor that constitutes a strong source of barriers to knowledge commercialisation. Therefore, one cannot demand that the system, which is constantly in motion, suddenly should start to work differently. Actions need to be taken to introduce gradual changes leading to the development of new systems, and thus effectiveness of support services provided by university dependent TTOs, Bls and STPs.

\section{References}

Acs, Z.J., Braunerhjelm, P., Audretsch, D.B. Carlsson, B. (2009). The knowledge spillover theory of entrepreneurship. Small Business Economy, 32, 15-30.

Chiesa, V., Piccaluga, A. (2000). Exploitation and Diffusion of Public Research: The Case of Academic Spin-off Companies in Italy. $R \& D$ Management, 30 (4), 329-339.

Clark, B.R. (1998). Creating Entrepreneurial Universities. Organizational Pathways of Transformation. IAU Press, Issues in Higher Education, Emerald.

Clarysse, B., Heirman, A., Degroof, J.-J. (2000). An institutional and resource-based explanation of growth patterns of research-based spin-offs in Europe. In: P.D. Reynolds (ed.), Frontiers of Entrepreneurship Research (pp. 545-559). Babson Park, MA: Babson College.

Davey, T., Meerman, A., Orazbayeva, B., Redel, M., Galan-Muros, V., Plewa, C., Eckert, N. (eds.). (2018). The Future of Universities Thoughtbook. University Industry Innovation Network.

Deiaco, E., Hughes, A., McKelvey, M. (2012). Universities as Strategic Actors in the Knowledge Economy. Cambridge Journal of Economics, 36 (3), 525-541.

Dietz, J.S., Bozeman, B. (2005). Academic careers, patents, and productivity: industry experience as scientific and technical human capital. Research Policy, 34 (3), 349-367.

Dosi, G., Nelson, R. (2010). Technical change and industrial dynamics as evolutionary processes. In: B. Hall, R. Nelson (eds.), Handbook of the Economics and Innovation (pp. 51-127), Vol. 1.

Etzkowitz, H., Webster, A., Gebhardt C., Terra B.R.C. (2000). The Future of the University and the University of the Future: Evolution of Ivory Tower to Entrepreneurial Paradigm. Research Policy, 29 (2), 313-330.

Glodek, P. (2016). Proces komercjalizacji wiedzy, a struktury uczelni wyższej - ujęcie modelowe. Prace Naukowe Uniwersytetu Ekonomicznego we Wrocławiu, 449, 155-168.

Glodek, P., Stawasz, E. (2017). University's Knowledge Transfer Capacity - Organisational Structures and Regional Cooperation. International Journal of Higher Education Management, 3 (2), 44-59.

Howard, J. (2005). The Emerging Business of Knowledge Transfer: From Diffusion to Engagement in the Delivery of Economic Outcomes from Publicly Funded Research. Turin, Italy: TripleHelix Conference 5: The Capitalization of Knowledge.

Kozmetzky, G., Williams, F., Williams, V. (2004). New Wealth. Commercialisation of Science and Technology for Business and Economic Development. Praeger.

Łobacz, K. (2012). Koncepcja oceny procesu komercjalizacji przedsięwzięć gospodarczych w akademickich inkubatorach przedsiębiorczości. Szczecin: Unpublished PhD thesis, University of Szczecin.

Łobacz, K., Niedzielski, P. (2015a). The interests of main stakeholders in the commercialisation process of business ventures within university business incubators. Optimum. Studia Ekonomiczne, 5, 53-76.

Łobacz, K., Niedzielski, P. (2015b). Uczelnie wyższe jako element procesu komercjalizacji wiedzy w Polsce - wyzwania i bariery. In: P. Głodek, M. Wiśniewska (eds.), Budowa potencjału uczelni wyższej do współpracy z przedsiębiorstwami (pp. 81-102). Lodź: Wydawnictwo Uniwersytetu Łódzkiego.

Matusiak, K.B., Guliński J. (eds.). (2010). System transferu technologii i komercjalizacji wiedzy w Polsce - siły motoryczne i bariery. Warszawa: PARP.

Mowery, D.C., Sampat, B.N. (2006). Universities in National Innovations Systems. In: J. Fagerberg et al. (eds), The Oxford Handbook of Innovation. Oxford University Press.

Shane, S. (2004) Academic Entrepreneurship. University Spinoffs and Wealth Creation. Cheltenham, UK, Northampton, MA: Edward Elgar Publishing. 
Knowledge transferer at universities: can technology transfer offices, husiness incubators and science and technology parks...

Trzmielak, T.M. (2013). Commercialisation of research results - cooperation between science and business. In: T.M. Trzmielak, J. Ropega (eds.), Innovations and knowledge commercialization Cooperative Resources (pp. 53-68). Łódź: Integrated Science and Business, Veritas et Libertas Universitas Lodziensis.

Zienkowski, L. (2003). Gospodarka oparta na wiedzy - mit czy rzeczywistość. In: L. Zienkowski (ed.), Wiedza a wzrost gospodarczy (pp. 13-32). Warszawa: Wydawnictwo Naukowe Scholar.

Cite this article as:' Łobacz, K. (2018). Knowledge transfer at universities: can technology transfer offices, business incubators and science and technology parks in Poland provide good support services? European Journal of Service Management, 4 (28/1), 181-189. DOI: 10.18276/ejsm.2018.28/1-23. 
